\title{
FoCUSING ON FraUd: THE FEDERAL GOVERNMENT Expands Its Use of the False Claims Act to Police Off-Label Pharmaceutical Promotion
}

\author{
Kristin McCreary Eichel ${ }^{*}$
}

In addition to ensuring that those who defraud the government will pay, cases like Pfizer send a strong message that if companies violate the law, if companies put profits ahead of patient health, we will hold them accountable. ${ }^{1}$

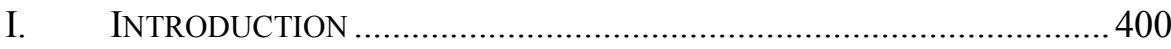

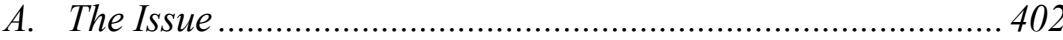

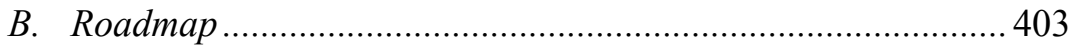

II. BACKGROUND: A LOOK INTO THE HISTORY SURROUNDING

REGULATION OF OFF-LABEL PROMOTION .................................... 403

A. Regulating Off-Label Promotion Under the FDCA ................. 403

1. The FDA's New Drug Approval Process .......................... 404

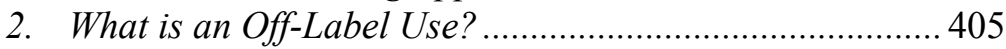

3. Violating the FDCA Through Off-Label Promotion........... 406

4. Is Off-Label Marketing Problematic? ................................ 407

a. Benefits of off-label use and marketing ..................... 407

b. Risks associated with off-label use and marketing .... 409

c. Defining acceptable promotion practices................... 410

B. Regulating Fraud and Off-Label Promotion Through the

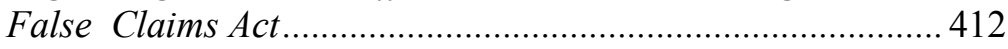

1. Noteworthy Provisions of the FCA................................... 412

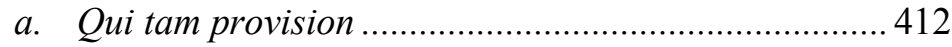

b. Possibility of government intervention ....................... 413

c. Threat of treble damages............................................ 414

2. Applying the FCA to Off-Label Promotion ........................ 414

III. ANALYSIS: TAKING A LOOK AT THE PHARMACEUTICAL

INDUSTRY'S LIABILITY FOR OFF-LABEL MARKETING AS

* J.D. Candidate, 2011, Indiana University School of Law-Indianapolis; B.A., 2006, Indiana University.

1. Tony West, Assistant Att'y Gen., U.S. Dep't. of Justice, Remarks at the National Association of Medicaid Fraud Control Units 2009 Annual Training Program (Sept. 14, 2009). 
THE SCOPE OF FEDERAL ENFORCEMENT CONTINUES TO

EXPAND THROUGH THE FALSE CLAIMS ACT ….............................. 416

A. The Expansion of the False Claims Act ...................................416

1. Executive Expansion of the FCA ..................................... 417

a. The DOJ has the ability to bypass FDA's regulatory authority to enforce federal law.................................. 417

b. Steady increase in amount and magnitude of settlements.

c. DOJ's focus on fraud.................................................... 421

2. Judicial Interpretation of the FCA .................................. 422

a. Franklin v. Parke-Davis ........................................... 423

b. An attempt to limit FCA expansion ............................. 424

3. Legislative Expansion of the FCA .................................... 427

a. Fraud Enforcement and Recovery Act amends the FCA .......................................................................... 427

b. Political climate ripe for increased legislation........... 428

$B$. The Effect of Continued FCA Expansion on the Pharmaceutical Industry.

C. The Federal Government Needs to Refocus Its Off-Label Enforcement Efforts .............................................................. 431

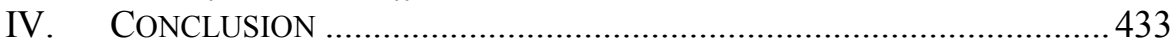

\section{INTRODUCTION}

On September 2, 2009, the Department of Justice announced the largest health care fraud settlement in United States history. Pfizer, one of the world's largest pharmaceutical companies, along with its subsidiary, Pharmacia \& Upjohn Company, Inc., ("Pfizer") agreed to pay the federal government $\$ 2.3$ billion in civil and criminal fines to resolve liability involving the illegal promotion of its pharmaceutical products. ${ }^{2}$ Although Pfizer's liability stemmed from its promotion of four different pharmaceuticals, the company's most egregious offense was the promotion of its antiinflammatory drug, Bextra. ${ }^{3}$

When Pfizer sought approval of Bextra in 2001, the FDA was only willing to approve the drug for a few specific uses. ${ }^{4}$ Most notably, the FDA

2. Press Release, U.S. Dep't. of Justice, Justice Department Announces Largest Health Care Fraud Settlement in Its History-Pfizer to Pay \$2.3 Billion for Fraudulent Marketing (Sept. 2, 2009), available at http://www.fbi.gov/pressrel/pressrel09/justice 090209.htm [hereinafter Pfizer Press Release].

3. $I d$.

4. See United States' Sentencing Memorandum at 5, United States v. Pharmacia \& UpJohn Co., No. 09-CR-10258-DPW (D. Mass. Oct. 9, 2009) (providing that the FDA approved Bextra for treatment of osteoarthritis, adult rheumatoid arthritis, and primary dysmenorrheal but "specifically declined to approve [Bextra's] use for general acute pain, the 
declined to approve Bextra for the treatment of acute pain due to safety concerns following a study of patients who were given Bextra after they underwent coronary artery bypass surgery. ${ }^{5}$ The results of the study indicated that there were an "excess of serious cardiovascular thromboembolic events," or blood clots, after Bextra was administered to the patients. ${ }^{6}$ However, despite the FDA's specific disapproval, Pfizer engaged in an elaborate marketing scheme to sell Bextra for its unapproved uses, particularly its use for acute pain, from 2002 through 2005 . $^{7}$ Some of the marketing techniques that Pfizer used to promote Bextra included the following: unsolicited medical information was sent to physicians about unapproved uses, samples of the drug were sent to surgeons who had no FDA-approved use for the drug, Pfizer sponsored "independent" medical education programs about unapproved uses, and Pfizer distributed to its sales force explicit instructions on how to promote the drug during sales calls to physicians. $^{8}$ Pfizer continued to promote Bextra for unapproved uses until it voluntarily pulled the drug from the market in 2005, at the FDA's request. $^{9}$

Pfizer's behavior with regard to its promotion of Bextra is known as "off-label" promotion, which occurs when a pharmaceutical company promotes its products for uses not approved by the FDA. ${ }^{10}$ Pharmaceutical manufacturers are generally prohibited from promoting their pharmaceutical products for off-label uses. ${ }^{11}$ However, because physicians are permitted to prescribe drugs for on-label and off-label uses, pharmaceutical manufacturers have an incentive to inform physicians about all of the possible uses of their products in order to increase sales. ${ }^{12}$ Therefore, when Pfizer promoted Bextra for off-label use, it risked legal culpability in order to reap the benefits of increased sales of the drug. In the end, Pfizer paid a monumental price for its decision to engage in off-label promotion.

preemption of the pain of surgery, and opioid sparing.").

5. Id.

6. $I d$.

7. Id. at 8 .

8. Id.

9. Id.

10. Pfizer Press Release, supra note 2.

11. The FDA has established guidance documents that pharmaceutical manufacturers should follow when disseminating information about off-label uses of their pharmaceuticals. Although the general rule is that no pharmaceutical manufacturer can promote off-label uses, the guidance documents provide a few exceptions to this general prohibition. This issue will be discussed more extensively in Section II of this note. See generally Office of the Commissioner, Good Reprint Practices for the Distribution of Medical Journal Articles and Medical or Scientific Reference Publications on Unapproved New Uses of Approved Drugs and Approved or Cleared Medical Devices, U.S. FOOD AND DRUG ADMINISTRATION, http://www.fda.gov/RegulatoryInformation/Guidances/ucm125126.htm (last updated Aug. 6, 2009) [hereinafter Good Reprint Practices].

12. See 21 U.S.C. § 353(b)(2) (2009); see also 21 U.S.C. $§ 396$ (2009). 


\section{A. The Issue}

Pfizer does not stand alone within the pharmaceutical industry in its decision to engage in off-label promotion. In fact, the practice seems to be commonplace. ${ }^{13}$ Although many other pharmaceutical manufacturers have settled claims involving off-label drug promotion recently, the magnitude of the Pfizer settlement demonstrates the seriousness of the federal government's enforcement efforts and its commitment to change this widespread behavior. $^{14}$

The sources of federal law that served as the basis for Pfizer's offlabel marketing liability were the Federal Food, Drug, and Cosmetic Act ("FDCA") and the False Claims Act ("FCA"). ${ }^{15}$ While the FDCA has traditionally been used to regulate illegal off-label marketing behavior, the use of the FCA as an additional legal tool to police the same behavior has only recently emerged. ${ }^{16}$ Attaching FCA liability to off-label marketing has not only made it possible for the Department of Justice ("DOJ") to pursue the pharmaceutical industry for putting the public's health at risk, but it has now permitted the DOJ to pursue the pharmaceutical industry with a justification that it is protecting the American taxpayers from health care fraud. ${ }^{17}$ The DOJ is no exception in its recent enforcement efforts under the FCA; in fact, all three branches of federal government have embraced this new theory of off-label promotion liability and have played some role in expanding the scope of the FCA.

The federal government has recently shifted from the traditional regulatory approach, with regard to off-label promotion by the pharmaceutical industry, to an enforcement and punishment approach. Currently, the government's focus seems to be more on punishing fraud than on balancing the risks and benefits of pharmaceuticals on the public health. ${ }^{18}$ No one can deny the federal government's strong interest in preventing a company's bottom line, as in the case of Pfizer, from taking priority over the public's health and safety. However, it is also necessary to hold the government accountable for overreaching their policing abilities. Recently, in the name of fraud, the federal government has rigorously pursued the pharmaceutical industry by attaching FCA liability to off-label promotion, despite the existence of the regulatory framework already in place to prevent this behavior.

13. See Top 20 Cases, TAXPAyers Against Fraud EducAtion Fund, http://www.taf.org/ top20.htm [hereinafter Top 20] (last visited Feb. 22, 2011).

14. See id.; see also Pfizer Press Release, supra note 2 (discussing the significance of the landmark Pfizer settlement).

15. Id.; see also The Federal Food, Drug, and Cosmetic Act, 21 U.S.C. $\S \S 301-399$ (2009); The False Claims Act, 31 U.S.C. $\S \S 3729-3733$ (2009).

16. See generally Top 20 Cases, supra note 13.

17. Pfizer Press Release, supra note 2.

18. See, e.g., West, supra note 1. 


\section{B. Roadmap}

This Note examines the recent enforcement efforts surrounding offlabel promotion in the pharmaceutical industry. Section II of this Note explores the regulatory and enforcement background in the off-label context, and begins by taking a look at the federal law that serves as the basis for off-label marketing liability, specifically, the FDCA. Additionally, Section II explores the past enforcement efforts by the federal agency charged with regulating off-label promotion under the FDCA, the FDA. Section II also introduces the basic elements of the FCA and shows how this federal antifraud statute has been used to impose liability on the pharmaceutical industry for off-label promotion. Section III of this Note demonstrates the FCA's recent expansion as applied to off-label promotion, and also shows how each branch of our federal government has contributed to the FCA's expansion in the off-label context. Additionally, Section III examines how the expansion of the FCA will likely affect the pharmaceutical industry and demonstrates that the FCA is not the most appropriate tool at the federal government's disposal when it comes to policing off-label promotion. Finally, Section III proposes that the federal government should leave offlabel regulation to the agency that is best equipped to balance the public's health and safety interests, the FDA. A brief conclusion is presented in Section IV.

\section{BACKGROUND: A LOOK INTO THE HISTORY SURROUNDING REGULATION OF OFF-LABEL PROMOTION}

\section{A. Regulating Off-Label Promotion Under the FDCA}

On June 24, 1938, Franklin D. Roosevelt signed the FDCA into law. ${ }^{19}$ The FDCA's purpose is to protect the health of the public by preventing adulterated or misbranded drugs from entering into interstate commerce. ${ }^{20}$ In 1938, Congress put the FDA in charge of a mandatory pre-market approval process for all new pharmaceutical products pursuant to the FDCA. ${ }^{21}$ The FDA remains responsible for conducting the pre-market approval process for prescription pharmaceutical products and is also responsible for

19. 21 U.S.C. $\S \S 301-399$. The Act's passage was a response to public concern over a health crisis that occurred in 1937, when a Tennessee company marketed an untested "wonder drug" that resulted in over 100 deaths, many of them children. See FDA History-Part II, U.S. FOOD AND DRUG ADMINISTRATION, http://www.fda.gov/AboutFDA/ WhatWeDo/ History/Origin/ucm054826.htm (last updated June 18, 2009) [hereinafter, FDA's Origin] (last updated June 18, 2009).

20. See Kordel v. United States, 335 U.S. 345, 349 (1948); 21 U.S.C. § 331 (2009).

21. 21 U.S.C. $\S \S 301-399$. 
overseeing drug marketing and labeling practices by the pharmaceutical industry. ${ }^{22}$

\section{The FDA's New Drug Approval Process}

The FDCA provides that "no person shall introduce or deliver for introduction into interstate commerce any new drug, unless an approval of an application filed ... is effective with respect to such drug.",23 Therefore, before a drug may be sold or marketed in the United States, the FDA must approve that drug's New Drug Application ("NDA"). ${ }^{24}$ But even before a drug manufacturer submits the NDA, the new drug must be approved for clinical trials. ${ }^{25}$ In other words, the drug manufacturer must prove that its drug is safe for human testing by obtaining pre-approval of its drug as an Investigational New Drug ("IND"). ${ }^{26}$ After IND approval and the subsequent clinical trials take place, the manufacturer is required to submit, through the drug's NDA, various information about the new drug such as: reports of investigations that show whether the drug is safe and effective for use, components of the drug, a statement about the composition of the drug, a description of the manufacturing, processing, and packaging methods, samples of the drug, and proposals for the labeling of the drug. ${ }^{27}$

As part of the NDA evaluation process, FDA officials determine whether the potential benefits of the new drug will justify the possible safety risks of the drug. ${ }^{28}$ In essence, the FDA engages in a cost/benefit analysis when deciding whether to approve a drug for entry into the market. If the benefits to the public health outweigh the risks, then the drug will be approved for the market, and the FDA will also get a say in what specific warnings or dosages go on the new drug's label. ${ }^{29}$

Once the FDA approves the new drug for introduction into interstate commerce, additional uses for the drug may not be added to that drug's label without submitting another NDA, a supplemental application for that

22. 21 U.S.C. $\S 355(2010)$.

23. 21 U.S.C. $\S 355(a)$.

24. Id.; Richard C. Ausness, "There's Danger Here, Cherie!" Liability for the Promotion and Marketing of Drugs and Medical Devices for Off-Label Uses, 73 BROOK. L. REV. 1253,1256 (2008).

25. 21 C.F.R. $\S \S 312.1-312.320$ (2010); About FDA: What is the Approval Process for a New Prescription Drug?, U.S. FoOD AND DRUG Administration, http://www.fda.gov /AboutFDA/Transparency/Basics/ucm194949.htm (last updated Jan. 5, 2010).

26. See generally, 21 C.F.R. $\S \S 312.1-312.320$ (2010).

27. 21 U.S.C. $\S 355(b)(1)$.

28. Rebecca Dresser \& Joel Frader, Off-Label Prescribing: A Call for Heightened Professional and Government Oversight, 37 J.L. MED. \& ETHICs 476, 477 (2009).

29. The FDA's Drug Approval Process: Ensuring Drugs are Safe and Effective, U.S. Food AND DRUG Administration, http://www.fda.gov/Drugs/ResourcesForYou/ Consumers/ucm143534.htm (last updated Feb, 22, 2010). 
drug. ${ }^{30}$ Therefore, a drug manufacturer must go through much of the drug approval process again in order to get approved for a new use of the drug. Because the new drug approval process is lengthy - estimates show that the average "time from the start of clinical testing to marketing approval [is] . . .90 .3 months"- many pharmaceutical manufacturers have figured out ways to circumvent the process. ${ }^{31}$ Also, if the drug is already on the market and being prescribed by physicians, and the only purpose of submitting a supplemental new drug application is for the ability to market the existing drug for a new use, a pharmaceutical company is unlikely to spend the money and time on the application. ${ }^{32}$ In other words, "[i]f an off-label use is already well known among physicians, adding it to the label would likely have little effect on sales." ${ }^{33}$

\section{What is an Off-Label Use?}

Although there is no explicit statutory definition of an off-label use, the term "off-label" takes root in the FDCA. ${ }^{34}$ Because the FDCA mandates FDA approval of a drug's specific use and additionally requires that such use be accurately reflected on the drug's label, a drug is used off-label when that use has not been approved by the FDA. ${ }^{35}$ However, the FDCA specifically exempts physicians from the labeling and prescription requirements that apply to drug manufacturers. ${ }^{36}$ Therefore, physicians are permitted to write prescriptions to patients for off-label use of a drug, without penalty under the FDCA. ${ }^{37}$ In fact, physicians take advantage of the exception, as it is estimated that between twenty-five to sixty percent of all prescriptions are written for off-label uses. ${ }^{38}$

An example of an off-label use would be if a physician treated a patient for acute pain with Pfizer's drug, Bextra. The FDA never specifically approved Bextra for the treatment of acute pain; therefore, the use of Bextra to treat acute pain would be considered an off-label use.

30. 21 C.F.R. $\S \S 314.54$ and 314.70 (2010).

31. Joseph A. DiMasi, et al., The Price of Innovation: New Estimates of Drug Development Costs, 22 J. Health \& ECON. 151, 164-5 (2003). See also, Kaspar J. Stoffelmayr, Comment, Products Liability and "Off-Label" Uses of Prescription Drugs, 63 U. CHI. L. REV. 275, 277 (1996).

32. See generally J. Howard Beales, III, Economic Analysis and the Regulation of Pharmaceutical Advertising, 24 Seton Hall L. ReV. 1370 (1994).

33. Stoffelmayr, supra note 31, at 277.

34. 21 U.S.C. $\$ \S 301-399$ (2009).

35. Stephanie Greene, False Claims Act Liability for Off-Label Promotion of Pharmaceutical Products, 110 PenN. ST. L. ReV. 41, 46 (2005).

36. 21 U.S.C. $\$ 353(b)$ (2009).

37. $I d$.

38. Nathan Cortez \& Robert Litt, Trends in Criminal Enforcement Against Off-Label Promotion, The American Bar Association's 21st Annual National Institute on White Collar Crime, L-23 to L-33 (2007). 


\section{Violating the FDCA Through Off-Label Promotion}

There are several different types of promotional activities employed by the pharmaceutical industry to boost a drug's sales, including: professional journal advertisements, magazine and newspaper advertisements, brochures, product giveaways, presentations at conferences, continuing medical education seminars, or company-sponsored events, oral statements by sales representatives during hospital visits, and many more. ${ }^{39}$ If a pharmaceutical manufacturer is promoting its products for FDA-approved uses, then these promotional activities are perfectly legitimate. However, as soon as the manufacturer promotes products for an off-label use, the marketing practices become illegitimate. $^{40}$

To clarify, there are two main ways that a drug manufacturer may violate the FDCA through its off-label promotion of a pharmaceutical product. The first type of violation occurs when a drug that was previously approved for certain uses, is promoted for other non-FDA approved uses, as the drug is effectively an unapproved "new drug" under the FDCA. ${ }^{41}$ The "FDA sees off-label promotion as the equivalent of introducing an unapproved new drug into interstate commerce in violation of the FDCA." 42 In essence, the FDA regards the off-label promotion of non-approved drug uses as if the pharmaceutical manufacturer skipped the NDA process altogether. Second, the FDA may hold a drug manufacturer liable for off-label promotion of a drug as a misbranding violation under the FDCA. ${ }^{43}$ Because the FDA approves each drug's particular label for certain uses and dosages during the NDA process, when a drug is promoted for a use other than the use on the label, the drug is considered misbranded. ${ }^{44}$ Pharmaceutical companies that introduce unapproved new drugs or misbranded drugs into interstate commerce can face civil and criminal penalties under the FDCA. ${ }^{45}$ Pfizer, for example, was held liable for misbranding the drug Bextra, ${ }^{46}$ and consequently, had to pay a fine of $\$ 1.195$ billion, the largest criminal fine ever imposed in our nation's history. ${ }^{47}$

39. Michelle M. Mello et al., Shifting Terrain in the Regulation of Off-Label Promotion of Pharmaceuticals, 360 New ENG. J. Med. 1557, 1557 (2009).

40. But see Good Reprint Practices, supra note 11 (discussing certain permitted offlabel communications); see also infra Section II(A)(5).

41. Id.; 21 U.S.C. $\S \S 321(\mathrm{p}), 331(\mathrm{~d}), 355(\mathrm{a})(2009)$.

42. Cortez \& Litt, supra note 38.

43. 21 U.S.C. $\S 331(b)(2009) ; 21$ U.S.C. $\S 352$ (2007).

44. 21 U.S.C. § 352; See also, generally Vicki W. Girard, Punishing Pharmaceutical Companies for Unlawful Promotion of Approved Drugs: Why the False Claims Act is the Wrong Rx, 12 J. HeAlth CARE L. \& POL'Y 119 (2009).

45. 21 U.S.C. $\S 333(2009)$.

46. Pfizer Press Release, supra note 2.

47. In total, Pfizer and its subsidiary, Pharmacia \& Upjohn, paid a criminal fine of $\$ 1.3$ billion in order to resolve criminal FDCA violations. This figure is one part of the total \$2.3 billion Pfizer settlement amount. See Pfizer Press Release, supra note 2. 


\section{Is Off-Label Marketing Problematic?}

There are benefits and risks associated with both off-label use and offlabel marketing. With respect to off-label use, experts in the legal and medical communities are divided on whether the practice should be more or less regulated. ${ }^{48}$ Concerning marketing, there are critics that contend the FDA should loosen regulation. ${ }^{49}$ Being that there are strong public policy arguments on both sides of these issues, the FDA is put in a difficult position. It is the FDA's responsibility to look out for the public's health while balancing the benefits of off-label use. Therefore, the FDA must walk a fine line when making decisions associated with off-label use and marketing. The agency must encourage the innovation needed to cure diseases and save lives, while also minimizing the risks associated with drugs that have not been rigorously tested for safety and effectiveness.

\section{a. Benefits of off-label use and marketing}

Many feel that off-label drug use is essential to providing patients with optimal medical care. ${ }^{50}$ Also, "because the pace of medical discovery runs ahead of the FDA's regulatory machinery, the off-label use of some drugs is frequently considered to be "state-of-the-art" treatment.", Thus, many feel that it is extremely beneficial to employ off-label uses of pharmaceuticals. Patients with terminal illnesses often depend on the innovative use of pharmaceuticals already on the market, especially when other drugs have failed to provide a cure during the course of their treatment. ${ }^{52}$ It is only logical that, for example, in the field of oncology, if one drug proves to be effective for a certain type of cancer, the drug may prove to be effective for another type. ${ }^{53}$ Even if the drug is not approved for the latter type of cancer, the patient would likely prefer to use that drug off-label rather than wait for the manufacturer to submit an NDA, because, after all, that patient will likely not have time to wait. Also, doctors tend to off-label prescribe for "socalled orphan populations and orphan diseases - populations too small and diseases too rare to justify the expense of petitioning the FDA for new la-

48. Tracy Hampton, Experts Weigh in on Promotion, Prescription of Off-Label Drugs, 297 JAMA 683, 683-84 (2007).

49. Alexander T. Tabarrok, Assessing the FDA Via the Anomaly of Off-Label Drug Prescribing, 5 THE InDEP. REV. 25, 48 (2000).

50. James M. Beck \& Elizabeth D. Azari, FDA, Off-Label Use, and Informed Consent: Debunking Myths and Misconceptions, 53 FOOD \& DRUG L.J. 71, 72 (1998).

51. Maxwell J. Mehlman, Off-Label Prescribing, The Doctor Will See You Now (May 1, 2005), http://www.thedoctorwillseeyounow.com/content/art1971.html (quoting Richardson v. Miller, 44 S.W.3d 1, 13 (Tenn. Ct. App. 2000)).

52. Tabarrok, supra note 49 , at 28.

53. Hampton, supra note 48, at 683. 
beling." ${ }^{, 54}$ Besides oncology, patient care in the medical fields of pediatrics, psychiatry, geriatrics, obstetrics, and many others, "could not proceed if offlabel prescribing did not occur." 55 Furthermore, the FDCA explicitly authorizes physicians to prescribe drugs for off-label uses. ${ }^{56}$ This explicit authorization is direct evidence that our legislature views off-label use as appropriate and necessary in many contexts. ${ }^{57}$

Promotion of off-label uses is also recognized as being very important for the pharmaceutical industry. The main benefit associated with the practice of off-label promotion "is to inform the health care community about scientific advances that will benefit patients, thus improving the quality of health care without waiting for the lengthy FDA approval process." ${ }^{\text {"N }}$ Ensuring that the medical community has up-to-date information about existing drugs that may be beneficial in the treatment of known ailments is a compelling reason to allow pharmaceutical companies to promote their unapproved products. Also, because the medical professional is the ultimate decision-maker when it comes to prescribing a drug for an off-label use, it seems harmless to inform them about potential off-label uses. ${ }^{59}$

The research and development that pharmaceutical companies perform is crucial to the progress of health and medical science. There is an undeniable benefit of disseminating information about possible curative drugs to physicians as well as the public. However, while society may try to give pharmaceutical companies the benefit of the doubt when it comes to producing safe and effective drugs as well as providing truthful information about those drugs, it cannot ignore the fact that pharmaceutical companies are also accountable to their shareholders for earning a profit. ${ }^{60}$

54. Tabarrok, supra note 49 , at 28.

55. Dresser \& Frader, supra note 28, at 476. Many drugs are not tested on certain groups of individuals (for example, children and pregnant women) and as a result, are not approved for safe use on these populations. As a consequence, children, pregnant women, or older individuals must use the drug off-label in order to benefit from several types of drugs. This does not necessarily mean that the drug is unsafe for use on these populations, but that the use is not approved by the FDA. See American Academy of Pediatrics, Committee on Drugs, Uses of Drugs Not Described in the Package Insert (Off-Label Uses), 110 Pediatrics 181 (2002). See also, Ausness, supra note 24, at 1254-55. However, also note that "the FDA have claimed to be speeding up and simplifying the supplemental approval process, especially with regard to the most significant "orphan" population, children. Tabarrok, supra note 49 , at 28.

56. 21 U.S.C. $§ 353($ b) (2004).

57. $I d$.

58. Greene, supra note 35 , at 47.

59. See Hampton, supra note 48, at 683.

60. See Marcia Angell, The Truth About the Drug Companies: How They Deceive Us And What To Do Aвout It 3 (Random House Trade Paperbacks, 2005) (noting that "[The pharmaceutical industry] has consistently ranked as the most profitable in the United States" and that "[the pharmaceutical industry earns] more than \$200 billion a year."). 


\section{b. Risks associated with off-label use and marketing}

It is a risky practice to distribute pharmaceuticals to the public without ensuring that the products are safe and effective for the condition they will be used to treat. As mentioned earlier, the FDA engages in a cost/benefit analysis when it approves drugs for particular uses. However, the problem with off-label use is that the drug did not have an opportunity to go through the FDA's formal analysis to determine safety and efficacy for a particular condition. The approval safeguards associated with drugs that have undergone the NDA process are not present when a physician prescribes a drug for an off-label use. While the FDA assumes physicians will ensure that an off-label use is generally accepted within the medical community before writing a prescription, "appropriate off-label prescribing can be challenging for physicians today, because of time pressures, information overload, and the involvement of industry in research and development about off-label uses. ${ }^{, 61}$ A 2009 study on U.S. physician knowledge of FDA-approved indications discovered that "many U.S. physicians may lack adequate knowledge of the FDA-approved indications of drugs they prescribe" and "a significant minority [of U.S. physicians] also prescribes some drugs for off-label indications, in the belief that they are approved for such uses, despite uncertain or no supporting evidence." ${ }^{, 2}$ Another study of off-label use by private practice physicians reported that only twenty-seven percent of off-label uses were supported by strong scientific evidence of clinical efficacy. ${ }^{63}$

Compared to off-label use, the risks associated with off-label promotion by pharmaceutical companies are more obvious, given the companies' interest in selling their products. The FDCA was originally enacted to protect the public from purchasing unsafe products and to keep businesses from marketing dangerous, untested drugs. ${ }^{64}$ In the past, pharmaceutical companies have been caught engaging in unethical and illegal off-label marketing practices. ${ }^{65}$ These companies tend to take advantage of the fact that physicians are busy people that may not have the time to seek out credible resources regarding off-label uses. One can guess that pharmaceutical companies hope that physicians will simply rely on the pharmaceutical sales representatives' assertions, or assume that the off-label research presented to them is unbiased and credible. ${ }^{66}$ For example, Pfizer's illegal

61. Dresser \& Frader, supra note 28 , at 476.

62. Donna T. Chen et al., U.S. Physician Knowledge of the FDA-Approved Indications and Evidence Base for Commonly Prescribed Drugs: Results of a National Survey, 18 Pharmacoepidemiology \& Drug SAFETy 1094, 1099 (2009).

63. Hampton, supra note 48 , at 683.

64. FDA's Origin, supra note 19.

65. See Top 20, supra note 13.

66. See, e.g., United States' Sentencing Memorandum, supra note 4. 
marketing scheme for the sale of Bextra, previously discussed in Section I, centered on influencing physicians to prescribe Bextra for its off-label uses. $^{67}$

\section{c. Defining acceptable promotion practices}

Before 1997, all off-label marketing attempts by the pharmaceutical industry were prohibited. ${ }^{68}$ Any attempts by a pharmaceutical manufacturer to discuss off-label uses with medical professionals, or to distribute written promotional materials to the medical community, were prohibited. ${ }^{69}$ Only when a physician solicited off-label use information did the FDA allow a manufacturer to disseminate that information. ${ }^{70}$

However, the Food and Drug Modernization Act of 1997 ("FDAMA") changed the FDA's prior position of prohibiting pharmaceutical manufacturers from off-label marketing. ${ }^{71}$ The FDAMA amended the FDCA to allow "drug . . . manufacturers to disseminate certain written information on a use of a product that is not described in the product's approved labeling to health care practitioners ..."72 The FDAMA provided that, in order to distribute off-label information, a pharmaceutical company must file with the FDA "[a] supplemental application based on appropriate research to establish the safety and effectiveness of the unapproved use.",73 Under the FDAMA, pharmaceutical manufacturers could send certain journal article reprints to physicians and discuss unapproved uses of drugs during continuing medical education seminars as long as the seminars were independent and not controlled or sponsored by the pharmaceutical company. ${ }^{74}$

Through the FDAMA, the FDA seemed to reach a balance between allowing for the dissemination of beneficial educational information on offlabel uses to the medical community, while ensuring that off-label promotional activities were still regulated. However, this balance expired on September 30, 2006, due to the FDAMA's sunset provision. ${ }^{75}$ Upon expiration of the FDAMA, the FDA subsequently issued "Good Reprint Practices," a

67. Id. See also, Pfizer Press Release, supra note 2.

68. Greene, supra note 35, at 49.

69. Id.

70. Id.

71. Testimony on the Implementation of the FDA Modernization Act of 1997 by Michael A. Friedman, M.D.: Hearing Before the H. Comm. on Commerce, 105th Cong. (1998) [hereinafter FDAMA Testimony] (citing statements by Michael A. Friedman, M.D., Acting Commissioner, Food and Drug Administration, U.S. Department of Health and Human Services).

72. Id.; Food and Drug Administration Modernization Act of 1997, Pub. L. No. 105$115, \S 401,111$ Stat. 2296, 2356 (1997) (codified as amended at 21 U.S.C. $\S 355$ et seq. (2000)).

73. FDAMA Testimony, supra note 71.

74. Greene, supra note 35, at 49.

75. Good Reprint Practices, supra note 11. 
set of guidance documents on dissemination of off-label educational materials, in order to fill the regulatory gap that the FDAMA left behind. ${ }^{76} \mathrm{Be}-$ cause the FDA recognizes "the public health value to healthcare professionals of receiving truthful and non-misleading scientific and medical information ..." the agency thought it was important to continue to allow guided dissemination of off-label information. ${ }^{77}$

Under the current Good Reprint Practices guidelines, issued on January 13, 2009, the FDA relaxes off-label restrictions even further than Con-

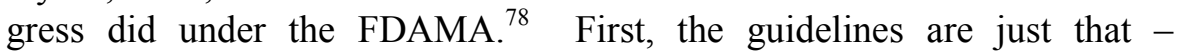
guidelines. Although issued by an administrative agency, they are nonbinding and are emphasized as such in the language of the guidelines. ${ }^{79}$ Next, submission of a supplemental new drug application is no longer required if a company decides to promote an off-label use. ${ }^{80}$ Finally, the FDA does not require the pharmaceutical manufacturer to submit its promotional materials prior to their distribution to the medical community. ${ }^{81}$

Although the FDA's current approach to off-label regulation is more relaxed than in the past, the current guidelines still only permit dissemination of journal articles and scientific reference publications that adhere to the FDA's specifications. ${ }^{82}$ Although off-label promotion is allowed in certain contexts, it is still prohibited in many other contexts. Therefore, sending out promotional samples at dosages not approved by the FDA would still be considered off-label promotion.

The FDA has met much criticism regarding its new guidelines, as some critics argue that the guidelines "could possibly harm public health by allowing manufacturers a back door for putting products into the health care setting for unapproved uses without having to . . gain FDA approval." ${ }^{\prime \prime 3}$ Furthermore, many believe that the FDA is ineffective in its regulation of

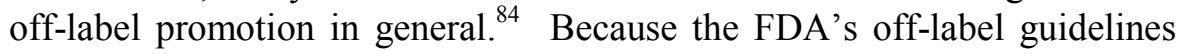
only address written promotional materials, other promotional practices go undetected, for example, when pharmaceutical sales representatives inap-

76. Id.; Ausness, supra note 24, at 1261 (discussing FDA's issuance of a version of Good Reprint Practices in 2008, with new guidelines recently issued on January 13, 2009).

77. § 401, 11 Stat. 2296, 2356-65; Good Reprint Practices, supra note 11.

78. Good Reprint Practices, supra note 11; Theresa Defino, New Guidelines on Distributing Literature on Off-Label Indications, NeUROLOGY TODAY, Mar. 5, 2009, at 14, 15.

79. Randall S. Stafford, Regulating Off-Label Drug Use - Rethinking the Role of the FDA, 358 NEW ENG. J. MED. 1427 (2008).

80. Id.

81. Id.

82. See Good Reprint Practices, supra note 11.

83. Mike Mitka, Critics Say FDA's Off-Label Guidance Allows Marketing Disguised as Science, 299 JAMA 1759 (2008); Stafford, supra note 79, at 1427.

84. See U.S. Gov't Accountability Office, Report to the Ranking Member, Committee on Finance, U.S. Senate, GAO-08-835, Prescription Drugs: FDA's Oversight of the Promotion of Drugs for Off-LABel Uses (2008), available at http://www.gao.gov/new.items/d08835.pdf. 
propriately discuss off-label uses with physicians. ${ }^{85}$ Whether the FDA has made a conscious decision not to pursue certain types of off-label promotional activity or is unable to detect the majority of off-label promotional activities due to limited resources, there are distinct regulatory gaps when it comes to the FDA's detection of off-label promotion. ${ }^{86}$

\section{B. Regulating Fraud and Off-Label Promotion Through the False Claims Act}

Also known as the "Lincoln Law," Congress passed the FCA in 1863 after pressure from President Abraham Lincoln "to combat profiteering by Union Army suppliers during the Civil War." ${ }^{87}$ The FCA has since become the federal government's primary tool for combating fraud. ${ }^{88}$ Generally speaking, the FCA prohibits false or fraudulent claims from being submitted to the government in order to procure government payment. ${ }^{89}$ Additionally, the FCA "provides an alternative strategy" to the FDCA to combat off-label promotion. ${ }^{90}$ Many view the FCA as "the single most important tool U.S. taxpayers have to recover the billions of dollars stolen through fraud by U.S. government contractors every year." 91

\section{Noteworthy Provisions of the FCA}

Although there are many facets of the FCA, there are a few provisions particularly relevant to this Note.

\section{a. Qui tam provision}

The FCA has a "qui tam" provision, also commonly referred to as a "whistleblower" provision. ${ }^{92}$ This qui tam provision enables private citizens to bring claims on behalf of the federal government. ${ }^{93}$ A citizen who

85. Id. at 6 .

86. See Id. See also Mello et al., supra note 39; Stafford, supra note 79, at 1429.

87. United States ex. rel. Stephens v. Tissue Science Laboratories, Inc., 664 F.Supp.2d 1310, 1315 (N.D. Ga. 2009) (citing United States ex. rel. Williams v. NEC Corp., 931 F.2d 1493, 1496-97 (11th Cir. 1991)); Larry D. Lahman, Bad Mules: A Primer on the Federal False Claims Act, 76 OKLA. B.J. 901, 901 (2005).

88. 31 U.S.C. $\$ \S 3729-3733$ (2006); Greene, supra note 35. 1496).

89. Stephens, 644 F.Supp.2d at 1315 (quoting U.S. ex. rel. Williams, 931 F.2d 1463 at

90. George S. Craft, Jr., Comment, Promoting Off-Label in Pursuit of Profit: An Examination of a Fraudulent Business Model, 8 Hous. J. HeAlth L. \& Pol'y 103, 112 (2007).

91. Why the False Claims Act: What is the False Claims Act and Why is it Important?, TAF EDUCATION FUND, http://www.taf.org/whyfca.htm [hereinafter Why the False Claims Act?] (last visited Feb. 22, 2011).

92. 31 U.S.C. $§ 3730(b)(1)$.

93. Id. 
brings a suit on behalf of the government is known as a qui tam "relator." Section 3730 of the FCA provides: "a person may bring a civil action for a violation of Section 3729 for the person and for the United States Government. The action shall be brought in the name of the Government." ${ }^{\text {" }}$ In a qui tam action, the relator stands to personally recover anywhere between fifteen and thirty percent of the proceeds of the action or settlement of the claim. ${ }^{95}$ This "encourag[es] individuals who are either close observers or involved in the fraud to report the alleged wrongdoing."

This qui tam provision is enormously effective at exposing fraudulent activity that may be too discrete for the federal government to notice. For example, the Pfizer settlement was ignited when several qui tam relators came forward to report the fraudulent activity that was a part of the company culture at Pfizer. ${ }^{97}$ Because Pfizer decided to settle with the federal government, the qui tam relators that were involved in the suit recovered over $\$ 102$ million dollars. ${ }^{98}$ John Kopchinski, a former Pfizer sales representative, was the highest paid relator in the settlement with a share of $\$ 51.5$ million. ${ }^{99}$ This payment was, in effect, compensation to Mr. Kopchinski for putting his career on the line in order to report his ex-employer's actions of defrauding the government through off-label marketing practices. ${ }^{100}$

\section{b. Possibility of government intervention}

After a qui tam relator brings a suit on behalf of the government, the government has an opportunity to intervene in the litigation. ${ }^{101}$ By intervening in the suit, the government will resume responsibility for the litigation. ${ }^{102}$ The qui tam relator is permitted to remain a party to the suit; however, the government is not bound by any act of the qui tam relator after intervention occurs. ${ }^{103}$

This qui tam provision benefits relators because he or she will still have the opportunity to recover a percentage of any amount retrieved by the government in the litigation, but will not incur the litigation costs that he or she otherwise would have incurred absent the government's intervention. ${ }^{104}$ Furthermore, government intervention usually leads to settlement in the off-

94. Id.

95. See 31 U.S.C. $\S 3730(d)(1)-(2)$.

96. Kenyanna M. Scott \& Catharine L. Du Bois, New Risk From Off-Label Promotional Activity, N.Y.L.J., Dec.12 2007, at 12.

97. Pfizer Settles Largest False Claims Act Case Ever, TAF EducATIOn Fund (Sep. 2, 2009) http://www.taf.org/whistle253.htm.

98. Id.

99. Id.

100. See generally Why the False Claims Act, supra note 91.

101. 31 U.S.C. $\$ 3730$ (a).

102. 31 U.S.C. $\$ 3730(c)(1)$.

103. Id.

104. See 31 U.S.C. $§ 3730$. 
label context because of the government's ability to threaten a manufacturer with exclusion from government reimbursement programs. ${ }^{105}$ A drawback to this provision, however, is that the government is required to investigate all qui tam actions brought by relators. ${ }^{106}$ The government thus has discretion to dismiss the qui tam relator's action after their investigation. ${ }^{107}$ By involving the government, a qui tam relator can either greatly benefit from the government's intervention or risk losing the suit entirely.

\section{c. Threat of treble damages.}

Another noteworthy provision of the FCA is the treble damages provision. ${ }^{108}$ If a person or an entity violates the FCA, they are "liable to the United States Government for a civil penalty of not less than $\$ 5,000$ and not more than $\$ 10,000$, plus three times the amount of damages which the Government sustains because of the act of that person."109 Further, the fines are assessed for each individual fraudulent claim. ${ }^{110}$ The threat of treble damages is one likely reason that many FCA cases are settled out of court.

\section{Applying the FCA to Off-Label Promotion}

The FCA has undergone several amendments since its inception in the nineteenth century. While past amendments have limited the scope of the FCA, amendments in the past three decades have broadened its scope. In 1986, Congress amended the FCA with the aim of "retooling [the Act] as an instrument capable of rooting out government fraud, particularly in defense as well as healthcare spending." "111 The 1986 amendments to the FCA increased the qui tam relator's potential share of the recovery, increased the penalties per FCA violation, and added the treble damages provision. ${ }^{112}$ Since 1986, false claims suits against the health care industry have risen drastically. ${ }^{113}$

As stated earlier in this Note, the FCA has become an additional enforcement tool used by the federal government to pursue off-label promotion violations. However, it is important to address the reasoning behind why off-label promotion creates FCA liability, especially considering that

105. The threat of exclusion will be discussed further in Section III of this Note.

106. 31 U.S.C. $\$ 3730$ (a).

107. 31 U.S.C. $\S 3730(\mathrm{c})(2)(\mathrm{a})$.

108. 31 U.S.C. $§ 3729(a)(1)(2006)$.

109. $I d$.

110. Scott \& Du Bois, supra note 96.

111. Edward P. Lansdale, Note, Used as Directed? How Prosecutors Are Expanding the False Claims Act To Police Pharmaceutical Off-Label Marketing, 41 New Eng. L. Rev. 159,170 (2006).

112. $I d$.

113. See Top 20, supra note 13. 
the term "off-label" takes root in the FDCA, and the consequences for promoting pharmaceutical products for off-label uses are provided for under the FDCA. ${ }^{114}$ So, how do prosecutors tie the practice of off-label promotion to liability under this federal fraud statute?

Pharmaceutical manufacturers depend a great deal on government reimbursement programs like Medicare and Medicaid to pay for sales of their prescription drugs. ${ }^{115}$ Under the FCA, if a pharmaceutical manufacturer causes the federal government to pay a false claim under Medicare, for example, as a result of their off-label marketing practices, the FCA may be used as a tool to recover the money that the government paid out to the manufacturer. ${ }^{116}$ In the history of regulating off-label promotion through the FCA, two legal arguments are usually made in order to attach liability to pharmaceutical manufacturers. ${ }^{117}$

One theory of liability under the FCA is to hold pharmaceutical companies "liable for making false claims about [their] drug."118 Certain offlabel uses are prohibited from reimbursement under federally funded government health care programs. ${ }^{119}$ Therefore, under this first theory, if a pharmaceutical sales representative make an untrue claim regarding the safety and effectiveness of their product to a physician, which in turn leads that physician to bill a federally-funded government health care program, such as Medicare, for reimbursement of that off-label use for their patient, then this action has the effect of causing a false claim to be made to the federal government.

A second, relatively new theory under the FCA was announced in the Parke-Davis case. ${ }^{120}$ If a pharmaceutical company's aggressive marketing eventually causes a party to improperly bill Medicaid, then that pharmaceutical company can be liable under the FCA. ${ }^{121}$ The Parke-Davis case held that:

[A qui tam] relator is not required to present evidence that [the pharmaceutical company] lied to physicians about [the drug's] off-label efficacy or safety to induce them to prescribe [the drug] for uses ineligible under Medicaid. . . . Truthful off-label marketing . . .

114. See generally 21 U.S.C. $\S \S 301-399$ (2006).

115. See, e.g., Scott \& Du Bois, supra note 96.

116. Greene, supra note 35, at 54 (citing 31 U.S.C. § 3729(a)(1) (2005)).

117. Lansdale, supra note 111, at 161.

118. Id.

119. See, e.g., 42 U.S.C. $§ 1396 r-8$ (2006).

120. See United States ex. rel. Franklin v. Parke-Davis, 147 F. Supp. 2d 39, 51 (D. Mass 2001); Lansdale, supra note 111, at 161.

121. Lansdale, supra note 111, at 161. 
and financial incentives like kickbacks would suffice. ${ }^{122}$

Therefore, liability under the FCA can arise when pharmaceutical manufacturers promote off-label uses of their products, even when the statements are credible, knowing that the federal government will reimburse the physician who prescribed its products.

Using the FCA as a tool to regulate behavior in the pharmaceutical industry has become much more common in the last decade. ${ }^{123}$ Federal prosecutors are thus pursuing pharmaceutical manufacturers under the FCA after the manufacturer violates the FDCA. As mentioned earlier, the FDA seems to lack the ability to police certain "off the record" instances of offlabel promotion. The qui tam provision gives insiders in the pharmaceutical industry the ability to police the off-label practices that the FDA cannot detect. However, critics wonder whether it is reasonable to attach FCA liability upon the pharmaceutical industry when the off-label marketing behavior is so loosely connected to the language of the statute and also, when off-label marketing is already specifically regulated by the FDCA. ${ }^{124}$ Whether one agrees or disagrees with the FCA's use in the off-label context, the reality is that the three branches of our federal government have all contributed to the gradual increase of the pharmaceutical industry's liability under the FCA.

\section{ANALYSIS: TAKING A LOOK AT THE PHARMACEUTICAL INDUSTRY'S \\ LIABILITY FOR OFF-LABEL MARKETING AS THE SCOPE OF FEDERAL ENFORCEMENT CONTINUES TO EXPAND THROUGH THE FALSE CLAIMS ACT}

\section{A. The Expansion of the False Claims Act}

As stated previously, the FCA has recently been used as an enforcement tool to police the practice of off-label marketing by the pharmaceutical industry. While the health care industry has been subject to FCA liability in the past, theories of potential liability related to off-label promotion by pharmaceutical manufacturers have only developed within the twenty-first century. ${ }^{125}$ This emerging method of targeting off-label marketing

122. Id. (quoting Judge Patti Saris in United States ex. rel. Franklin v. Parke-Davis, No. 96-11651, 2003 U.S. Dist. LEXIS 15754 at 4 (D. Mass. Aug. 22, 2003)).

123. See Top 20, supra note 13.

124. See generally Girard, supra note 44.

125. Robert T. Rhoad et al., A Gathering Storm: The New False Claims Act Amendments and Their Impact on Healthcare Fraud Enforcement, 21 THE HEALTH LAW. 14 (2009); See also Ralph F. Hall \& Robert J. Berlin, When You Have a Hammer Everything Looks Like a Nail: Misapplication of the False Claims Act to Off-Label Promotion, 61 FoOD \& DRUG L.J. 653 (2006). 
has not only developed quickly, but has flourished ${ }^{126}$ and the expansion of the FCA is now apparent in all three branches of our federal government. While not all expansion efforts are directly related to policing off-label promotion, the widening scope of the FCA will surely affect the pharmaceutical industry. And this expansion of FCA application continues to occur without thorough judicial consideration of whether its use is really proper in the off-label context.

\section{Executive Expansion of the FCA}

More than any other branch of government, the executive branch has extended the FCA's reach to off-label promotion practices the furthest. The executive department that has primarily contributed to this expansion is the Department of Justice ("DOJ"), the federal department responsible for enforcing federal laws. Although other federal agencies contribute to the investigative and enforcement efforts related to off-label promotional activities, the DOJ is the primary enforcement agency for violations of the FCA as well as the FDCA. ${ }^{127}$ This was not always the case, however, as in the past the FDA exclusively oversaw off-label marketing practices, primarily through a regulatory approach to enforcement. ${ }^{128}$

\section{a. The DOJ has the ability to bypass FDA's regulatory authority to enforce federal law}

There are two ways in which the DOJ may become involved with offlabel promotional prosecutions. First, the FDA can initiate DOJ's involvement in the enforcement of off-label promotional violations. ${ }^{129}$ If the FDA decides that its regulatory efforts are not correcting improper off-label promotional behavior by a pharmaceutical company, the FDA can refer the violations to the DOJ for civil or criminal enforcement action. ${ }^{130}$ As an alternative to adhering to the traditional FDA-initiated enforcement method, the DOJ can also initiate investigations and prosecutions of off-label marketing violations on its own. ${ }^{131}$ It is through this latter method of enforce-

126. See Top 20, supra note 13.

127. See, e.g., Scott A. Memmott \& Betsy McCubrey, Off-Label Marketing Prosecutions and Cephalon: The Government Hits Its Stride and Hits Hard, 11 J. Health Care COMPLiAnce 55 (2009); see also U.S. Gov't AcCOUnTABILITY OfFICE, supra note 84. Although the FDA is an administrative agency under the executive branch of our federal government, the FDA has not contributed to the expansion of the FCA as it relates to off-label promotion. The FDA's regulatory roll takes root under the FDCA.

128. John N. Joseph et al., Enforcement Related to Off-Label Marketing and Use of Drugs and Devices: Where Have We Been and Where Are We Going? 2 J. HEALTH \& LiFE SCI. L. 73, 73 (2009).

129. U.S. Gov'T ACCOUNTABILITY OfFICE, supra note 84, at 2.

130. Id.

131. Id. at 19 . 
ment that the DOJ imposes FCA liability on pharmaceutical manufacturers that the FDA may not have otherwise imposed.

When a pharmaceutical manufacturer decides to market a drug for an off-label use, the FDA regulates that manufacturer's behavior solely through the FDCA. ${ }^{132}$ However, because the DOJ enforces federal law, the DOJ can prosecute that same illegal off-label marketing behavior under the both the FDCA and the FCA. ${ }^{133}$ Therefore, a pharmaceutical manufacturer that is pursued by the DOJ can be liable for both FDCA and FCA violations. ${ }^{134}$

It is disconcerting that the DOJ's prosecutorial investigations of pharmaceutical companies for off-label marketing are triggered by violations of the FDCA and not the FCA. Although it is appropriate for the DOJ to pursue FDCA violations, the agency that controls and ensures compliance with the FDCA, the FDA, is usually not initially involved in the prosecutions. ${ }^{135}$ Basically, the FCA claim would not exist if not for a violation of the FDCA.

Although, as discussed earlier, the DOJ can initiate off-label prosecutions without direction from the FDA, it is qui tam relators that usually make the DOJ aware of a pharmaceutical manufacturer's off-label marketing practices. Because qui tam relators have great monetary incentives for reporting their company's off-label marketing schemes, off-label suits brought by qui tam relators are extensive. ${ }^{136}$ After a qui tam relator files suit, the DOJ will investigate the relator's allegations and decide whether to intervene in the litigation. ${ }^{137}$ Once the DOJ decides to investigate a pharmaceutical manufacturer for off-label marketing, the department will usually contact the FDA to assist in the investigation and resolution of the suit. ${ }^{138}$ If the DOJ does decide to intervene in the qui tam suit, a settlement agreement between the DOJ, FDA, and the accused manufacturer usually follows.

Therefore, FCA suits initiated by qui tam relators are a significant initiator of the DOJ's off-label enforcement agenda. ${ }^{139}$ The use of the FCA in the off-label arena has enabled qui tam relators and the DOJ to take the

132. See 21 U.S.C. $\S \S 301-399$ (2006).

133. The DOJ enforces off-label marketing behavior through additional federal laws as well, however, a discussion of all of the additional off-label enforcement methods is beyond the scope of this note.

134. See, e.g., Pfizer Press Release, supra note 2.

135. U.S. GOV'T ACCOUNTABILITY OFFICE, supra note 84, at 19.

136. 31 U.S.C. $\S 3730(d)(1)(2006)$.

137. 31 U.S.C. $\S 3730$.

138. U.S. Gov'T ACCOUNTABILITY OfFICE, supra note 84, at 19.

139. See generally Michael Rich, Prosecutorial Indiscretion: Encouraging the Department of Justice to Rein in Out-of-Control Qui Tam Litigation Under the Civil False Claims Act, 76 U. CIN. L. REV. 1233 (2008) (discussing how the FCA's qui tam relator incentives influence the DOJ when prosecuting fraud under the FCA). 
place of the FDA when it comes to regulating and enforcing the pharmaceutical industry's off-label promotion practices.

\section{b. Steady increase in amount and magnitude of settlements}

Throughout the past decade there has been a steady increase in the magnitude of damages collected through off-label settlements as well as the amount of cases settled for off-label violations. ${ }^{140}$ The threat of treble damages, mentioned in Section II, is one apparent reason why pharmaceutical manufacturers are unwilling to take a gamble at trial for violating the FCA. ${ }^{141}$ But even beyond this strong deterrent, the DOJ has another tool at its disposal to encourage settlement of FCA claims. This powerful settlement-inducement tool is known as "debarment," which is the exclusion of a pharmaceutical company or its products from federal government health care reimbursement programs, like Medicare and Medicaid. ${ }^{142}$ Critics characterize the threat of exclusion, or debarment, from federal reimbursement programs as a "nuclear threat" or a "corporate death sentence" due to the fact that "exclusion can completely choke off a company's revenue stream by eliminating access to the patients who buy the drugs."143 As a result, pharmaceutical manufacturers likely see it as imperative to cooperate with federal prosecutors in the DOJ when this threat is on the table.

Between 2003 and 2007, the DOJ has settled at least eleven cases involving off-label marketing allegations against various pharmaceutical companies. ${ }^{144}$ Of these settlements, at least nine involved the imposition of civil monetary fines through the FCA. ${ }^{145}$ For the fiscal year 2009, the DOJ reported FCA recoveries totaling over $\$ 2.4$ billion. ${ }^{146}$ This FCA recovery amount was the second largest since the expansive 1986 amendments to the FCA. ${ }^{147}$ This increase of the number and magnitude of settlements involving pharmaceutical manufacturers for off-label promotional behavior continues to rise. ${ }^{148}$ The DOJ only demonstrates an intention to continue this

140. The False Claims Act Legal Center: Statistics, TAF EdUCATION Fund, http://www.taf.org/statistics.htm [hereinafter TAF Statistics] (last visited Feb. 22, 2011).

141. See 31 U.S.C. $\$ 3729$ (2006); Hall \& Berlin, supra note 125, at 676.

142. See 42 U.S.C. $§ 1320$ a-7 (2006); Hall \& Berlin, supra note 125, at 676.

143. Hall \& Berlin, supra note 122, at 676; Lansdale, supra note 111, at 181.

144. U.S. Gov'T ACCOUNTABILITY OFFICE, supra note 84, at 37.

145. TAF Statistics, supra note 140.

146. FY 2009 False Claims Act Settlements, TAF EduCATION Fund, http://www.taf.org/total2009.htm (last updated Oct. 1 2009).

147. Joe Palazzolo, DOJ Recovers \$2.4 Billion in False Claims Act Cases, MaIN Justice (Nov. 19, 2009), http://www.mainjustice.com/2009/11/19/doj-recovers-2-4-billionin-civil-fraud-cases.

148. See, e.g. Top 20, supra note 13; see also Erica Teichert, Allergan Agrees to Plead Guilty and Pay $\$ 600$ Million to Resolve Allegations of Off-Label Promotion of Botox, FIERCE PhARMA (Sept. 2, 2010), http://www.fiercepharma.com/press_releases/allergan-agreesplead-guilty-and-pay-600-million-resolve-allegations-label-promotion; see also David Voreacos, Elan will Pay $\$ 203$ Million to Settle Illegal Marketing Probe of Zonegran, 
billion-dollar recovery pattern. ${ }^{149}$ One of the more significant contributing factors of the DOJ's large 2009 fiscal recovery under the FCA was the landmark Pfizer settlement. ${ }^{150}$

When Pfizer settled allegations of off-label promotion in September of 2009 , the pharmaceutical giant made health care fraud history with the $\$ 2.3$ billion settlement figure. ${ }^{151}$ The Pfizer settlement began when several qui tam whistleblowers filed suit under the FCA in various federal district courts throughout the United States. ${ }^{152}$ When the qui tam whistleblowers brought the off-label allegations as well as evidence of those allegations, the DOJ decided to intervene in the suit. Several district attorneys' offices as well as many federal agencies, including the FDA, played a role in investigating the allegations against Pfizer. ${ }^{153}$ This settlement, although initiated by qui tam relators and primarily pursued by federal prosecutors, was resolved through a concerted effort by various interested federal agencies. ${ }^{154}$

Pfizer was accused of violating both the FDCA and the FCA through its off-label marketing practices. ${ }^{155}$ Of the $\$ 2.3$ billion settlement figure, $\$ 1.3$ billion resolved the company's criminal liability under the FDCA and the remaining $\$ 1$ billion resolved allegations that the company "caused false claims to be submitted to government health care programs for uses that were not medically accepted indications and therefore not covered by those programs," or in other words, resolved potential liability under the FCA. ${ }^{156}$ Additionally, \$102 million of the federal government's FCA recovery was divided among the six qui tam whistleblowers. ${ }^{157}$

As mentioned earlier, Pfizer's most serious off-label marketing offenses were related to its pain and anti-inflammatory drug, Bextra. ${ }^{158}$ Under the settlement agreement, Pfizer agreed to plead guilty to a felony misbranding charge under the FDCA for the off-label marketing of Bextra. ${ }^{159}$ Pfizer's off-label marketing behavior with regard to Bextra was deliberate.

BLOOMBERG (Dec. 16, 2010), http://www.bloomberg.com/news/2010-12-15/elan-agrees-topay-203-million-to-settle-u-s-probe-of-zonegran-marketing.html; see also Press Release, U.S. Dep't of Justice, Kos Pharmaceuticals to Pay More Than 41 Million to Resolve Kickback and Off-Label Promotion Allegations (Sept. 2, 2009), available at http://www.justice.gov/opa/pr/2010/December/10-civ-1402.html.

149. See, e.g., Effective Strategies for Preventing Health Care Fraud: Hearing Before the S. Comm. on the Judiciary, 111th Cong. (2009) [hereinafter West Strategies] (statement of Tony West, Assist. Att'y Gen. of the United States), available at http://www.justice.gov/dag/testimony/2009/dag-testimony-091028.html.

150. See discussion, supra Section I.

151. Pfizer Press Release, supra note 2.

152. Id.

153. Id.

154. Id.

155. Id.

156. Id.

157. Id.

158. See discussion, supra Section I.

159. Specifically, Pfizer was charged with violating 21 U.S.C. $\S \S 331(a), 333(a)(2)$, and 352(f) (2006). See United States' Sentencing Memorandum, supra note 4, at 1. 
The company's intention was to mislead and coerce physicians into prescribing Bextra for off-label uses. ${ }^{160}$ As a result, Pfizer was punished for this behavior under the FDCA. The $\$ 1.195$ billion dollar penalty was the largest criminal penalty ever imposed in the United States. ${ }^{161}$ However, Pfizer's punishment for its off-label marketing behavior went even further.

Pfizer also settled FCA liability with regard to Bextra. ${ }^{162}$ However, beyond the FCA's qui tam feature that enabled Pfizer employees to bring Pfizer's off-label marketing behavior to the federal government's attention, Pfizer's specific violation of the FCA is still unclear. And because Pfizer did not make an admission during the settlement with regard to any FCA liability for the promotion of Bextra or the other three pharmaceutical products that it was charged with violating under the FCA, there is not much detail with regard to Pfizer's specific improper actions. ${ }^{163}$ However, we do know that Pfizer caused claims to be submitted to federal reimbursement programs through physicians for off-label uses of its drugs. ${ }^{164}$ And despite a lack of knowledge with regard to the specifics of the DOJ's FCA allegations against Pfizer, it is evident that the threat of exclusion from government-backed health care programs was a factor in Pfizer's willingness to pay such a high settlement amount related to FCA liability.

The Pfizer settlement also implies that a pharmaceutical company will likely pay out millions, if not billions of dollars, if an off-label marketing scheme can be proven or even alleged by the federal government. It seems that if the government can target off-label marketing by a pharmaceutical manufacturer, then FCA liability will follow. In essence, the FCA provides a way for federal prosecutors to 1) discover off-label marketing violations that the FDA otherwise would not have discovered, and 2) increase the penalty for the off-label marketing scheme in order to recover more money for the federal government.

\section{c. DOJ's focus on fraud}

The DOJ has continued to exhibit its intention to prosecute fraud whenever possible. When announcing recent off-label promotion settlements, although the importance of safety within the pharmaceutical industry is often mentioned, the announcements focus more on the recovery of taxpayer dollars through the FCA. ${ }^{165}$

160. See generally United States' Sentencing Memorandum, supra note 4 (demonstrating overall off-label scheme by Pfizer to sell its drug, Bextra, for FDA-unapproved uses).

161. The total criminal penalty was $\$ 1.3$ billion; Pfizer paid $\$ 1.195$ billion and Pharmacia and Upjohn paid \$105 million. See Pfizer Press Release, supra note 2.

162. Id.

163. Id.

164. Id.

165. Id. 
Policing health care fraud and recovering funding for government health care programs are stated priorities of the DOJ: "the DOJ . . recognizes both the urgency in the need to recover those funds and the need to ensure that such fraud does not reoccur." ${ }^{166}$ In May 2009, to demonstrate its focus on fraud and the recovery of funds for the federal government, the DOJ announced the creation of the Health Care Fraud Prevention and Enforcement Action Team ("HEAT"). ${ }^{167}$ The HEAT task force is comprised of the DOJ, the Department of Health and Human Services ("HHS"), as well as other state and federal law enforcement agencies. ${ }^{168}$ HEAT contributed to the 2009 Pfizer settlement. ${ }^{169}$ Additionally, much like the assistance given by qui tam relators to detect FCA violations, HEAT is calling upon the general public for assistance in the detection, prevention, and prosecution of fraud. ${ }^{170}$

In his speech before the Senate Judiciary Committee, Tony West, U.S. Assistant Attorney General, stated, "We have a duty to the taxpayers. . . . While most medical or pharmaceutical providers are doing the right thing, when Medicare or Medicaid fraud occurs, it costs the American taxpayers real dollars. . . It is those wrongdoers who we must stop." ${ }^{\text {171 }}$ Traditionally, the concern that would arise when a pharmaceutical manufacturer chose to market its drugs for off-label uses was that the public's health and safety was put at risk because the marketed drugs had not been put to appropriate safety and efficacy tests. Currently, when a pharmaceutical manufacturer decides to engage in off-label marketing, the main concern seems to be that the manufacturers are defrauding government programs that are funded by taxpayer dollars. ${ }^{172}$ The victims of off-label marketing are no longer users of the pharmaceuticals; rather, the victims are now the American taxpayers. No matter how the DOJ frames the issue, the victims of off-label marketing are admittedly the American public. Nonetheless, because the DOJ is shifting the off-label marketing issue's focus to fraud, the DOJ is using the political climate to push an agenda that expands the scope of the FCA.

\section{Judicial Interpretation of the FCA}

The judicial branch of government has contributed the least to the expansion of the FCA. In fact, the Supreme Court of the United States attempted to limit the FCA's application, although this limitation was not

166. West Strategies, supra note 149.

167. Id.

168. Id.

169. Id.

170. Id.

171. Id.

172. See Pfizer Press Release, supra note 2. 
within the off-label context. ${ }^{173}$ Many FCA qui tam suits related to off-label promotion are dismissed in the early stages of litigation, especially when the federal government does not intervene or join in the suit. ${ }^{174}$ For example, many qui tam relators have trouble surviving motions to dismiss because they do not plead their fraud claim with particularity. ${ }^{175}$ Furthermore, no reported FCA case related to off-label marketing has ever gone to trial. Therefore, FCA claims related to off-label marketing violations have still not undergone sufficient judicial review. ${ }^{176}$

However, despite the procedural difficulties that qui tam relators may face when bringing an FCA claim, the judicial system has nonetheless expanded FCA liability to the pharmaceutical industry for off-label marketing violations. A single judicial opinion effectively opened the floodgates to the pharmaceutical industry's potential liability for off-label marketing under the FCA. ${ }^{177}$ Through one denial of a motion to dismiss, the district court judge created significant leverage for the executive branch when negotiating settlements for off-label marketing with the pharmaceutical industry. ${ }^{178}$

\section{a. Franklin v. Parke-Davis}

The Parke-Davis case proved to be groundbreaking because it legitimized the use of the FCA to pursue pharmaceutical manufacturers for offlabel marketing. ${ }^{179}$ Although Justice Saris' opinion was based on a denial of Parke-Davis' motion to dismiss a qui tam relator's suit, the opinion has nevertheless proved to be enormously influential.

The qui tam relator in Parke-Davis, Dr. David Franklin, brought suit against his former employer, Parke-Davis, a pharmaceutical manufacturer, for liability under the FCA. ${ }^{180}$ Specifically, Dr. Franklin alleged that Parke-

173. See Allison Engine Co. v. United States ex rel. Sanders, 553 U.S. 662 (2008).

174. See, e.g., United States ex rel. Rost v. Pfizer, Inc., 466 F. Supp. 2d 6 (2006); see also United States ex. rel. Stephens v. Tissue Science Laboratories, Inc., 664 F.Supp.2d 1310 (N.D. Ga. 2009; see also Hopper v. Solvay Pharmaceuticals, Inc. 588 F.3d 1318 (11th Cir. 2009).

175. See, e.g. Hopper, 588 F.3d 1318; see also, U.S. ex rel. Bennett v. Medtronic, Inc. 747 F.Supp.2d 745 (S.D. Tex. 2010).

176. See Girard, supra note 44.

177. See United States ex. rel. Franklin v. Parke-Davis, 147 F. Supp. 2d 39 (D. Mass. 2001).

178. Id.

179. Lansdale, supra note 111, at 189 (discussing that the Parke-Davis case also "represents the emergence of a new legal theory that allows federal prosecutors to hold pharmaceutical companies liable under the FCA for making otherwise truthful statements [about their products] that cause others to submit improper claims against the public fisc."). Although there is a strong debate about whether truthful off-label promotion would be considered the basis for FCA liability, this particular debate is not the focus of this note.

180. Parke-Davis, 147 F. Supp. $2 \mathrm{~d}$ at 51. 
Davis' off-label promotion of its drug, Neurontin, caused the submission of false claims to federal health care programs. ${ }^{181}$

Although Parke-Davis conceded that an off-label prescription that causes reimbursement by Medicaid would be considered a false claim under the FCA, the company argued that because the company itself did not submit the false claim for government payment, it could not be held liable under the FCA. ${ }^{182}$ The company asserted that Dr. Franklin could not establish causation under the FCA because physicians and patients constituted intervening causes that broke the chain of legal causation. ${ }^{183}$ However, the court refused to dismiss Dr. Franklin's suit because although the physicians, pharmacists, and patients were intervening forces in the chain of ParkeDavis' false claim submission, those actors were foreseeable intervening forces, which do not break causal connections. ${ }^{184}$ The court stated that "the participation of doctors and pharmacists in the submission of false Medicaid claims was not only foreseeable, it was an intended consequence of the alleged scheme of fraud." ${ }^{185}$ Furthermore, Parke-Davis' off-label statements about their drug, Neurontin, were found to be material to the government's decision to reimburse claims for the drug. ${ }^{186}$

The denial of Parke-Davis' motion to dismiss legitimized the theory of FCA liability for off-label marketing by pharmaceutical manufacturers. The court established that the causal link between a manufacturer's offlabel promotion scheme and the eventual submission of a claim for repayment to federal health care programs was foreseeable. ${ }^{187}$ Further, the court acknowledged that false statements about a product's off-label usage could materially influence the federal government's decision to reimburse a claim for an off-label use. ${ }^{188}$ The recognition that these two elements of a FCA claim could apply in the context of a manufacturer's scheme of off-label marketing expanded the scope of the FCA and proved to be great news for qui tam relators and the federal government.

\section{b. An attempt to limit FCA expansion}

On June 9, 2008, the Supreme Court of the United States announced its unanimous decision to limit the scope of the FCA. ${ }^{189}$ The case, Allison Engine v. Sanders, while not related to off-label marketing, did involve many of the same FCA provisions used to attach off-label liability to phar-

181. Id.

182. Id.

183. Id.

184. Id.

185. $I d$.

186. $I d$.

187. Id.

188. Id.

189. Allison Engine Co. v. United States ex rel. Sanders, 553 U.S. 662 (2008). 
maceutical manufacturers. ${ }^{190}$ In Allison Engine, the Supreme Court limited application of the FCA so as not to "transform the FCA into an all-purpose antifraud statute." However, just eleven short months after the Allison Engine decision was published, it was superseded by legislation. ${ }^{191}$

The Allison Engine case involved a contract to build guided missile destroyers for the United States Navy ("Navy"). ${ }^{192}$ The Navy contracted with two shipbuilders to build the destroyers, and each destroyer required three generator sets to power the ship. ${ }^{193}$ The shipbuilders then subcontracted with Allison Engine Company ("Allison Engine") to build the generator sets for all of the destroyers, who in turn subcontracted with General Tool Company ("GTC"), who in turn subcontracted with Southern Ohio Fabricators, Inc. ("SOFCO"). ${ }^{194}$ The Navy made sure to include specifications for each destroyer into each of the subcontractors' contracts. ${ }^{195}$

Two former employees of GTC brought a FCA suit as qui tam relators against Allison Engine, GTC, and SOFCO (collectively "Subcontractors") for submitting invoices to the shipbuilders (not the Navy) for reimbursement of their work. ${ }^{196}$ The qui tam relators alleged that the Subcontractors had not built the generator sets in accordance with the Navy's contract specifications and, therefore, fraudulently sought payment from the federal government under the FCA. ${ }^{197}$

The Supreme Court rejected the lower court's decision that it is enough for a plaintiff to show that a false statement resulted in the government's payment of a false claim. ${ }^{198}$ Instead, the Supreme Court held that defendants must have an intent "to get" a false claim paid by the government under the FCA's statutory language. ${ }^{199}$ The court held that it was not enough that a false claim be paid using government funds; therefore, the court reversed in favor of the Subcontractors. ${ }^{200}$ The court noted that an elimination of the intent requirement would expand the FCA "well beyond its intended role of combating "fraud against the Government.",201 Because the Subcontractors intended that the shipbuilders, rather than the federal government, pay them for building the generator sets and because there was

190. Id

191. See discussion of the federal law that superseded the Allison Engine decision, infra Section III(C).

192. Allison Engine, 553 U.S. at 665.

193. Id.

194. Id.

195. Id.

196. Id. at 666-67.

197. Id.

198. $I d$. at 668 .

199. Id.

200. Id. at 673 .

201. Id. at 669 . 
no proof that the Subcontractors had the intent to defraud the government itself, the Subcontractors were not liable under the FCA. ${ }^{202}$

This unanimous decision by the Supreme Court seemed to suggest the court's desire to limit the scope of the FCA. The Subcontractors in Allison Engine arguably had a much closer link to a government payout than any pharmaceutical manufacturer may have to government reimbursement of an off-label prescription. Nevertheless, the Supreme Court felt that the link was too attenuated and declined to attach FCA liability to the Subcontractors. ${ }^{203}$ The Supreme Court reasoned that when a defendant makes a false statement to a private entity for reimbursement without the intention that the government rely on that false statement as a condition of payment, then the "direct link between the false statement and the Government's decision to pay or approve a false claim is too attenuated to establish [FCA] liability." 204 It is quite possible that a pharmaceutical company could apply the Supreme Court's analysis in Allison Engine to defeat FCA claims based on off-label marketing by asserting a "direct link" defense to government payout or claim a lack of intent to influence payment by the federal government.

What is interesting about the Allison Engine decision is that the dispute in question involved a more traditional application of the FCA. As mentioned earlier, the FCA was enacted during the Civil War in order to prevent profiteers from hindering the war effort with "rampant fraud and shoddy supplies." 205 The Allison Engine case involved Navy shipbuilders that claimed reimbursement for work that did not adhere to the Navy's specifications. ${ }^{206}$ Therefore, even when applying the language of the FCA to a more traditional fact pattern, the Supreme Court limited liability. ${ }^{207}$ Because FCA liability tied to off-label marketing schemes is based on less traditional legal arguments than the arguments made in Allison Engine, it is not too far-fetched to predict that our Supreme Court may also limit liability in the off-label context based on the language of the FCA.

After the announcement of the Allison Engine decision, it was not long before many defendants used the case to assert defenses against FCA claims by qui tam relators. ${ }^{208}$ Although Allison Engine demonstrates that courts are willing to limit the scope of FCA liability, the Parke-Davis opinion still holds to expand liability for off-label marketing under the FCA. In fact, in a recent case brought by a qui tam relator against a pharmaceutical

202. Id. at $672-73$.

203. Id. at 672 .

204. Id.

205. Lansdale, supra note 111 , at 168.

206. Allison Engine, 553 U.S. at 665.

207. See Id.

208. United States ex rel. Kennedy v. Aventis Pharmaceuticals, Inc., 610 F. Supp. 2d 938 (N.D. Ill. 2009). 
manufacturer involving allegations of off-label liability under the FCA, the pharmaceutical manufacturer cited the Allison Engine decision in its motion to dismiss the relator's claims. ${ }^{209}$ The defendant pharmaceutical manufacturer emphasized, by quoting the Allison Engine opinion, that under the FCA, "a defendant is answerable for "the natural, ordinary and reasonable consequences of his conduct, though not for anything beyond that."210 However, the district court rejected the manufacturer's use of Allison Engine as a defense in favor of the reasoning in Parke-Davis. ${ }^{211}$ The district court applied the Parke-Davis foreseeability approach instead of the direct link approach to causation. ${ }^{212}$ Therefore, at least in terms of the causation element under the FCA as applied to off-label marketing, a court was willing to allow the claim to survive a motion to dismiss and the Parke-Davis foreseeability approach to causation was favored over the direct link approach in the off-label context. ${ }^{213}$ This case demonstrates how influential the Parke-Davis reasoning is when applying the FCA to off-label marketing by pharmaceutical manufacturers. ${ }^{214}$

Despite the Supreme Court's attempt to limit FCA liability in the Allison Engine case, the FCA has still been interpreted quite liberally in the offlabel marketing context. ${ }^{215}$ Thus, although many FCA qui tam claims get dismissed in the early stages of litigation, the Parke Davis reasoning still serves as an expansion to off-label liability under the FCA.

\section{Legislative Expansion of the FCA}

In addition to executive and judicial expansion of the FCA, the legislative branch has also contributed to the recent expansion of the FCA. In a swift response to the Allison Engine decision, Congress passed the Fraud Enforcement and Recovery Act of 2009, the most significant amendment to the FCA since $1986 .{ }^{216}$

\section{a. Fraud Enforcement and Recovery Act amends the FCA}

The Fraud Enforcement and Recovery Act of 2009 ("FERA") was enacted on May 20, 2009. ${ }^{217}$ The stated purpose of the legislation was to "reinvigorate our Nation's capacity to investigate and prosecute the kinds of

209. Id.

210. Id. (quoting Allison Engine, 553 U.S. at 665).

211. Kennedy, 610 F. Supp. $2 d$ at 944.

212. $I d$.

213. Id.

214. Id.

215. See, e.g., id. at 938.

216. The Fraud Enforcement and Recovery Act of 2009, Pub. L. No. 111-21, 123 Stat. 1617 (2009).

217. Id. 
financial frauds that have so severely undermined our financial markets and hurt so many hard working people in these difficult economic times."218 While the legislation was not specifically related to health care or off-label marketing, FERA actually widened the scope of the FCA. Therefore, it will likely affect the pharmaceutical industry in the off-label context.

One Senate Judiciary Committee Report outlining the purpose of FERA addressed the reasoning for FERA's amendments to the FCA. The report stated, "[t]he effectiveness of the FCA has recently been undermined by court decisions limiting the scope of the law. . . . [T] he FCA must be corrected and clarified in order to protect [from fraud] the Federal assistance and relief funds expended in response to our current economic crisis." 219 Specifically, in the Senate report, Congress was referring to the Allison Engine decision's interpretation of the FCA's scope. ${ }^{220}$ In enacting FERA, Congress eliminated the requirement of intent announced in Allison Engine. $^{221}$ Now there is no requirement for a qui tam relator or the federal government to establish a direct link between a false statement and the eventual government payment of the claim. ${ }^{222}$ As amended, the FCA now only requires that an entity or an individual knowingly or recklessly attempt to defraud the government. ${ }^{223}$ Therefore, while the Allison Engine Court tried to avoid transforming the FCA into an "all-purpose antifraud statute," Congress effectively overturned the Court's decision by expanding the FCA into just that. ${ }^{224}$ As a result of FERA, potential FCA liability may attach to any company or individual that conducts business in the health care industry. $^{225}$

\section{b. Political climate ripe for increased legislation}

FERA was passed at a time when the United States' economy was quite vulnerable. FERA was primarily a response to the bank and mortgage lending crises. Congress' opinion was that the United States was in "the most serious economic crisis since the Great Depression." 226 In a struggle to pull the economy out of imminent downturn, Congress took action by placing the blame for the state of the union on fraud by big businesses and

218. S. REP. No. 111-10, at 3 (2009).

219. S. REP. No. 111-10, at 10.

220. S. REP. No. 111-10, at 10-11.

221. See Allison Engine Co, v. U.S. ex re.l Sanders, 553 U.S. 662 (2008).

222. Rhoad et al., supra note 125, at 17.

223. Letter from M. Faith Burton, Acting Assistant Att'y Gen., U.S. Dep't of Justice, to Patrick J. Leahy, Chairman, Comm. on the Judiciary, U.S. Senate (April 1, 2009), available at http://www.justice.gov/ola/views-letters/111-1/040109-s386-fraud-enforcement-recoveryact.pdf.

224. Allison Engine, 553 U.S. at 672.

225. Rhoad et al., supra note 125 , at 16.

226. S. REP. No. 111-10, at 2. 
sought to make available any tool at the federal government's disposal to deter and punish those businesses. The Senate Judiciary Committee Report on the background of FERA demonstrates this point:

To make sure this kind of collapse cannot happen again, we must invigorate our anti-fraud measures and give law enforcement agencies the tools and resources they need to root out fraud so that it can never again place our financial system at risk. Taxpayers, who bear the burden of this financial downturn, deserve to know that the Government is doing all that it can to hold responsible those who committed fraud in the run-up to this collapse. ${ }^{227}$

As a result, the powerful enforcement tool that has been used to reach off-label marketing was strengthened. Therefore, when enacting FERA's amendments to the FCA, Congress did not fail to mention how important the legislation was to fixing our nation's broken economy in the wake of the banking crisis. ${ }^{228}$

Congress did not hesitate to take advantage of the current political climate when expanding the scope of a major tool that the federal government uses to extract funding from companies that defraud the federal government. Imbedded in FERA, an economic recovery bill, were amendments to a federal law that has the ability to do significant damage to any business that is directly or indirectly paid with government funds. ${ }^{229}$ An enforcement tool that is capable of such severe damage seems worthy of more legislative consideration. However, because the FCA is such an effective tool at recovering money for the federal government, Congress did not hesitate to expand its scope.

\section{B. The Effect of Continued FCA Expansion on the Pharmaceutical Industry}

The days of commonplace off-label promotion in the culture of the pharmaceutical industry seem to be coming to a close. When taking the actions of all three branches of the federal government as a whole, it is conceivable that pharmaceutical manufacturers' potential liability under the FCA will only continue to increase. Although the above three sections addressed each branch of government's contribution to the expansion of the FCA separately, it is important to take a look at the cumulative effect of the federal government's expansion of the FCA on the pharmaceutical industry.

227. S. ReP. No. 111-10, at 3.

228. S. REP. No. 111-10, at 8 .

229. See generally The Fraud Enforcement and Recovery Act of 2009, Pub. L. No. 11121, 123 Stat. 1617 (2009). 
First, it is unlikely that FERA's amendments to the FCA will have a very noticeable effect on off-label litigation, at least in the courts. ${ }^{230}$ The reason that post-FERA FCA cases will "feel" the same as pre-FERA cases, at least when the DOJ intervenes in the litigation, is because most off-label FCA cases do not make it to trial due to the threat of exclusion and treble damages. ${ }^{231}$ Because most off-label cases settle, it will be difficult to measure the actual affect that FERA's amendments will have on off-label litigation. ${ }^{232}$ In the case of qui tam suits where the government declines to intervene, qui tam litigants may have stronger cases against pharmaceutical manufacturers due to the expanded scope of the FCA's language.

However, just because it will be difficult to actually see the effects of FERA in the off-label context, does not mean that FERA will not affect the pharmaceutical industry. FERA's expansion of the FCA will give federal prosecutors more leverage when negotiating settlements with pharmaceutical companies for off-label marketing violations. Now, instead of relying on the Parke-Davis precedent, federal prosecutors will have more backing under the law through the new, expansive statutory language. ${ }^{233}$ But, as discussed previously, the DOJ already possesses a great deal of leverage against pharmaceutical manufacturers.

The only hope the pharmaceutical industry may have for limiting liability under the FCA for off-label marketing is if a pharmaceutical manufacturer decides to take the risk of litigation against a qui tam relator. The judicial branch seems the most willing to rein in the DOJ's and Congress' use of the FCA. Furthermore, the Parke-Davis decision only involved a motion to dismiss in a district court. ${ }^{234}$ Other federal or district courts may interpret an off-label case differently or use a different standard of review than that employed in a motion to dismiss. However, many pharmaceutical manufacturers were not willing to take a chance on litigation before FERA. Because FERA expanded the FCA's scope, it is even more unlikely that a pharmaceutical manufacturer would take the risk to litigate. Furthermore, the Court would likely interpret an off-label case similarly to the ParkeDavis decision.

The DOJ has recently been given the political green light by Congress to pursue fraud whenever possible. ${ }^{235}$ The powerful anti-fraud tool that the

230. Drew Harker \& Mahnu Davar, Arnold \& Porter LLP, Presentation, The 2009 False Claims Act Amendments and Implications for the Pharmaceutical and Medical Device Industry (Oct. 23, 2009), available at http://www.arnoldporter.com/resources/documents /CBI\%20FERA_FCA\%20Off-label\%20Slides\%20--\%20Harker\%20and\%20.pdf.

231. Id.

232. $I d$.

233. See generally The Fraud Enforcement and Recovery Act of 2009, Pub. L. No. 11121, 123 Stat. 1617 (2009).

234. United States ex. rel. Franklin v. Parke-Davis, 147 F. Supp. 2d 39, $43-44$ (D. Mass 2001).

235. See S. REP. No. 111-10, at 3. 
DOJ possessed and used against pharmaceutical manufacturers in the past for off-label marketing enforcement became even more powerful through FERA. ${ }^{236}$ Because the DOJ has demonstrated an increased pursuit of the pharmaceutical industry throughout the past decade, it is unlikely that this trend will stop, especially with additional support from Congress. ${ }^{237}$ It is likely not coincidental that the landmark Pfizer settlement occurred only three months after the FERA amendments were passed and the HEAT task force was created. ${ }^{238}$

Some critics argue that the massive settlement amounts will not stop the pharmaceutical industry from continuing to promote their pharmaceutical products for off-label uses. ${ }^{239}$ Because the pharmaceutical industry is a multi-billion dollar industry, many companies have the ability to include potential settlement amounts into their business plans. ${ }^{240}$ For example, when Pfizer settled with the DOJ for $\$ 2.3$ billion, the billion-dollar figure was accounted for in Pfizer's fourth quarter earnings. ${ }^{241}$ However, this settlement amount decreased Pfizer's quarterly profit by ninety percent. ${ }^{242}$ Furthermore, the settlement amounts have only increased over the years. ${ }^{243}$ If settlements continue on the path of costing pharmaceutical companies billions of dollars, off-label promotion may not continue to be commonplace in the industry.

It is clear at this point that liability for off-label marketing under the FCA is not going to disappear any time soon. The goal of recovering taxpayer dollars in the wake of a troubled economy may be noble; however, the federal government's focus on this goal is clouding its judgment when deciding the proper tool to use when regulating off-label marketing.

\section{The Federal Government Needs to Refocus Its Off-Label Enforcement Efforts}

The federal government needs to reassess its aggressive enforcement of the pharmaceutical industry with regard to off-label marketing under the FCA. FDCA law already provides for actions by pharmaceutical manufacturers to promote their products for off-label uses. When the DOJ pursues a pharmaceutical manufacturer for off-label marketing violations, the bases for those pursuits are the manufacturer's violation of the FDCA. As the

236. Rhoad et al., supra note 125 , at 14 .

237. See generally id.

238. See generally Pfizer Press Release, supra note 2; See also The Fraud Enforcement and Recovery Act of 2009, Pub. L. No. 111-21,123 Stat. 1617 (2009).

239. Tom Murphy, Fines Unlikely to Halt Off-Label Drug Promos, InDianapolis STAR (Sept. 5, 2009), available at http://www.mdjonline.com/printer_friendly/3531953.

240. Id.

241. Id.

242. Id.

243. See, e.g., Top 20 Cases, supra note 13. 
federal government began focusing on fraud by the pharmaceutical industry under the FCA, it lost sight of the policy goals underlying the FDCA.

The FDA, through the FDCA, has traditionally regulated off-label marketing by the pharmaceutical industry. ${ }^{244}$ The FDCA provides that the FDA may call upon the DOJ to enforce violations of its provisions, if the FDA chooses to do so. ${ }^{245}$ This regulatory framework should remain intact. Scholars contend that, "[v]iolations of a specific statutory structure such as the FDCA should be handled by that statutory system."246 The FDA, not qui tam relators or the DOJ, is "specifically charged with implementing the public health goals of the [FDCA]."247 Although the DOJ, particularly through the FCA's qui tam provisions, has uncovered massive off-label violations, the "advantages associated with focusing on correction and compliance should not be cast aside without careful consideration of the impact on the [FDCA's] primary goal of promoting and protecting the public health." 248

There is a clear disconnect between the FDA's pursuit of pharmaceutical manufacturers for off-label marketing and the DOJ's pursuit of pharmaceutical manufacturers for off-label marketing. The FDA has recently expanded the pharmaceutical industry's ability to promote its products for off-label uses. ${ }^{249}$ Meanwhile, other branches of our federal government are expanding potential liability for the off-label promotion of pharmaceutical products under the FCA. Because the legal and medical communities alike hotly contest the benefits and risks of off-label use, it makes much more sense to leave the debate within the control of the experts employed at the FDA. ${ }^{250}$ The FDA is in the best position to balance the benefits and risks of off-label use and marketing and can issue guidance with regard to proper marketing practices. Furthermore, the FDA can affect the pharmaceutical manufacturers' off-label marketing behavior through already provided-for punishment mechanisms within the FDCA. ${ }^{251}$

However, in order for the FDA to take back complete control of offlabel marketing investigation and regulation, the FDA must fix its regulatory gaps. The FDA has been criticized for its inability to detect off-label marketing violations by the pharmaceutical industry. ${ }^{252}$ Therefore, the FDA needs to increase its off-label marketing investigations. For example, the FDA can consider increasing oversight of off-label promotional activities in contexts in which pharmaceutical companies usually promote to physi-

244. Hall \& Berlin, supra note 125 , at 56-57.

245. See generally 21 U.S.C. $\S \S 301-399$.

246. Hall \& Berlin, supra note 125, at 674 .

247. Girard, supra note 44, at 143.

248. Id. at 148-49.

249. See generally Good Reprint Practices, supra note 11.

250. See generally Girard, supra note 44.

251. See generally 21 U.S.C. $\S \S 301-399$ (2009).

252. See generally U.S. Gov't ACCOUnTABILITy OfFICE, supra note 84. 
cians - in continuing medical education seminars and in hospitals. The FDA can also conduct better oversight of promotional materials that lack strong scientific support. ${ }^{253}$ It may even be possible for the FDA to begin a campaign to provide financial incentives to physicians and others who report off-label promotion by pharmaceutical companies. ${ }^{254}$ This system could mimic the role of FCA qui tam relators.

One benefit of FCA qui tam litigation, as mentioned previously, is that it has unveiled various off-label marketing techniques employed by pharmaceutical manufacturers. ${ }^{255}$ The FDA has previously been unable to detect these types of marketing techniques because they are done behind closed doors. However, now that qui tam litigators have revealed these various techniques, the FDA can devote its resources to detecting these violations.

\section{CONCLUSION}

The FCA's main purpose is to prevent fraud perpetrated upon the federal government. Despite the fact that the FCA does not provide any specific penalty for off-label promotion, the federal government has successfully connected the pharmaceutical industry's off-label marketing schemes to a purported intention to defraud the federal government. At first blush, this connection seems to make some sense. After all, the pharmaceutical industry depends upon federal health care reimbursement programs for a large percentage of its profits. Therefore, when a pharmaceutical manufacturer engages in illegal off-label promotion, this promotion will eventually cause a claim to be submitted to a government health care reimbursement program for an off-label use. Thus, when the federal government reimburses the pharmaceutical manufacturer based on an initial illegal action, the manufacturer is effectively defrauding the federal government. The DOJ justifies its rampant pursuit of pharmaceutical manufacturers based on this train of thought. Through this justification, the federal government has effectively recharacterized traditional public policy considerations under the FDCA, while pursuing FCA liability for off-label marketing.

No one can deny the public's interest in punishing pharmaceutical companies for deliberately putting the public's health at risk in order to turn greater profits. However, it is important that the federal government uses the correct enforcement tools to punish off-label marketing behavior. Because FCA liability for off-label marketing always starts with a violation of the FDCA, the FDCA, and not the FCA, is the proper federal law to enforce

253. Stafford, supra note 79 , at 1429.

254. Adriane Fugh-Berman \& Douglas Meinick, Off-Label Promotion, On-Target Sales, 5 PLoS MED. 1432,34 (2008).

255. See United States' Sentencing Memorandum, supra note 4. 
off-label marketing violations. The recent expansion of the FCA encourages pharmaceutical manufacturers to settle cases when faced with liability for off-label marketing under the FDCA. The theories of FCA liability in the off-label context are deserving of judicial review before these coercive settlements continue.

In conclusion, the FDA is best suited for regulating the pharmaceutical industry. The FDA is able to balance the risks and benefits surrounding off-label use and promotion and can also use enforcement tools already provided-for under the FDCA to ensure the pharmaceutical industry's compliance with the law. 